\title{
Synthetic Cathinone and Cannabinoid Designer Drugs Pose a Major Risk for Public Health
}

\begin{abstract}
Aviv M. Weinstein ${ }^{1 *}$, Paola Rosca ${ }^{2}$, Liana Fattore ${ }^{3}$ and Edythe D. London ${ }^{4,5,6}$
${ }^{1}$ Department of Behavioral Science, Ariel University, Ariel, Israel, ${ }^{2}$ Department for the Treatment of Substance Abuse, Ministry of Health, Jerusalem, Israel, ${ }^{3}$ Institute of Neuroscience-Cagliari, National Research Council of Italy, Cagliari, Italy, ${ }^{4}$ Department of Psychiatry and Biobehavioral Sciences, University of California Los Angeles, Los Angeles, CA, United States, ${ }^{5}$ Department of Molecular and Medical Pharmacology, University of California Los Angeles, Los Angeles, CA, United States, ${ }^{6}$ Brain Research Institute, University of California Los Angeles, Los Angeles, CA, United States
\end{abstract}

As part of an increasing worldwide use of designer drugs, recent use of compounds containing cathinones and synthetic cannabinoids is especially prevalent. Here, we reviewed current literature on the prevalence, epidemiology, bio-behavioral effects, and detection of these compounds. Gender differences and clinical effects will also be examined. Chronic use of synthetic cathinone compounds can have major effects on the central nervous system and can induce acute psychosis, hypomania, paranoid ideation, and delusions, similar to the effects of other better-known amphetamine-type stimulants. Synthetic cannabinoid products have effects that are somewhat similar to those of natural cannabis but more potent and long-lasting than THC. Some of these compounds are potent and dangerous, having been linked to psychosis, mania, and suicidal ideation. Novel compounds are developed rapidly and new screening techniques are needed to detect them as well as a rigorous regulation and legislation reinforcement to prevent their distribution and use. Given the rapid increase in the use of synthetic cathinones and cannabinoid designer drugs, their potential for dependence and abuse, and harmful medical and psychiatric effects, there is a need for research and education in the areas of prevention and treatment.

Keywords: synthetic drugs, cathinones, cannabis, amphetamine, new psychoactive drugs

\section{INTRODUCTION}

Over the past decade, there has been a worldwide increase in the opportunity for use and consumption of Novel Psychoactive Substances (NPS) - which produce "legal highs" (1-8). Usually mimicking the psychoactive effects of illicit drugs of abuse, these "designer" drugs vary widely in composition, and are mainly sold online and from street retailers. Some of the drugs are advertised as being legal and are often labeled as "not for human consumption" or "licensed by the Ministry of Health," to bypass-legislation enforcement. Based on their pharmacological mechanisms and psychoactive properties, designer drugs fall into four major categories: (i) amphetamine-like stimulants, which include cathinones derivatives and piperazine derivatives that are sold as substitutes for "ecstasy," (ii) synthetic cannabinoids, (iii) hallucinogenic/dissociative agents, and (iv) opioid-like compounds (9). While new compounds are appearing relentlessly on the drug market, information regarding their potential toxicity is scarce and the number of emergencies related to their use is increasing $(10,11)$. Given the public health threat that is growing in complexity, a multidisciplinary coordinated effort is required to elucidate the acute and chronic effects of synthetic drugs of abuse (12). According to 
the World Drug Report 2016 (13), the majority of the substances reported for the first time between 2012 and 2014 were synthetic cannabinoids, followed by synthetic cathinones that have been steadily increasing since their first appearance (2010). Synthetic cathinones and synthetic cannabinoids have been studied more extensively than other classes of NPS (e.g., new hallucinogens and opioid-like compounds) over the past 10 years. These two classes of substances are the most popular, both induce central and peripheral serious effects and activate the brain reward system thus showing to possess abuse potential $(14,15)$. Since they pose a major health hazard potential, this review will focus on these two classes of NPS.

Synthetic cathinones are psychostimulants related to the naturally occurring parent compound cathinone $(16,17)$, a monoamine alkaloid found in the khat plant (Catha edulis), a flowering plant native to the Horn of Africa and the Arabian Peninsula that is being chewed in these areas for thousands of years. Cathinone is a psychoactive substance known to cause excitement, loss of appetite, and euphoria. As members of the phenethylamine class of drugs, they are structurally and pharmacologically similar to amphetamine and 3,4-methylenedioxymethamphetamine (MDMA). The most commonly used drugs in this class have been 4-methylmethcathinone (mephedrone), 3,4-methylenedioxy- $N$-methylcathinone (methylone), and 4-methylenedioxypyrovalerone (MDPV), although MDPV and mephedrone are no longer prevalent $(16,17)$. Reports of abuse of cathinone derivatives date back to the 1990s, when mephedrone was the first designer drug of this class (18). Mephedrone is the most widely abused synthetic cathinone in Europe, and MDPV and methylone are the most frequently abused synthetic cathinones in the United States (7). These drugs have been commonly referred to as "bath salts," "plant food," or "fertilizer," because they were at times disguised and commonly included in products that were labeled and sold as such $(7,9)$. New analogs, legal to possess, at least until they are formally banned, are frequently introduced, and it has been estimated that nearly 250 new analogs are produced each year (19). These drugs are consumed by oral ingestion, inhalation, and snorting. Notably, the recent trend to supplement use of more conventional psychostimulants, such as amphetamine and cocaine, with mephedrone, may lead to serious psychotic, neurological, cardiovascular, and sexual health consequences (4).

Synthetic cannabinoid receptor agonists, which often mimic the effects of marijuana, are added to herbs, such as Damiana leaves, and sold under different brand names, such as "Spice" or Mr. Nice Guy in Europe since 2006 (20, 21). These products are also called "K2," "herbal incense," "Cloud 9," "Mojo," and with many other names (22). Advertised as "exotic incense blends which release a rich aroma," Spice, and Spice-like preparations in Europe have been found to contain different substances with various chemical structures, including those (i) based on over 450 compounds originally produced for medical research by John W. Huffman (e.g., JWH-018), (ii) HU-210 developed by Raphael Mechoulam at the Hebrew University, and (iii) the cyclohexylphenol ("CP") cannabinoids developed at Pfizer Pharmaceuticals (23). AM-2201, an indole derivative, which differs from JWH018 by a fluorine atom in the pentyl chain, is commonly found in
Korea and has nanomolar affinity for cannabinoid receptors (24). After the appearance on the drug market of over 100 compounds that activate cannabinoid receptors, new compounds with different chemical structures that directly or indirectly stimulate the cannabinoid CB1 receptors are expected. The perceived harmfulness of synthetic cannabinoids among secondary school students (twelfth grade) increased between 2012 (the first year of measurement) and 2014, which may have contributed to the decline in use (9). This review is divided into the following categories: epidemiology of use, pharmacology, neuropsychiatric findings, other medical conditions, and regulation.

\section{EPIDEMIOLOGY}

\section{Synthetic Cathinones}

Masticating khat leaves has been a social habit among Saudi Arabian and East African cultures, for several centuries. Cathinone is the main psychoactive ingredient that was detected in the leaves of the C. edulis. In the Middle East and in East Africa khat use is still common, more among men than women, although the gap is narrowing (25). Yet, although both sexes typically report to use khat to upkeep of tradition, men's use is more frequently associated to recreational purposes, while women often report to use it to treat headache or lose weight (26).

Recent surveys have considered the problem of synthetic cathinones use in the United States. In an online survey of 113 participants, who reported use of synthetic cathinones, respondents were males, with age range of 18-24 years, and Caucasian holding college education (27). Their use in the past year was low ( $\leq 10$ days), but recurrent. The intranasal route of administration was most frequently reported, and its effects were similar to those of cocaine and amphetamines. Synthetic cathinones increased sexual desire and sexual risk-taking behavior. More than half of the responders met DSM-V diagnostic criteria for a substance-related disorder. Self-reported prevalence of the use of synthetic cathinones was less than that of marijuana, cocaine, Salvia divinorum, synthetic cannabinoids, methamphetamine, and MDMA. In another survey, reaching over 2,300 students at a large university in the Southeastern United States, $1.07 \%$ of respondents endorsed ever using synthetic cathinones, and those who did were more often men than women, Hispanics, and Native American rather than Caucasian students, and athletes more than non-athletes (27).

Studies of synthetic cathinones use in Europe have also been informative. In Hungary, there has been a shift among street drug users from the use of heroin to mephedrone injection, potentially increasing the risk of severe psychiatric symptom profile and increased possibility of dependence (28). Among 1,000 individuals who completed a survey in schools and universities in Scotland (49.8\% males and 50.2\% females), $20.3 \%$ reported previous use mephedrone, with $23.4 \%$ reporting single use and $4.4 \%$ daily use (29). In a survey of 249 NPS users interviewed in open public places, clubs, and discotheques in Slovenia, $67.9 \%$ of the respondents endorsed having tried either synthetic cathinones or amphetamines (30). Of those who reported using synthetic cathinones or amphetamines, most reported having used 
3-methylmethcathinone first, $43.0 \%$ had first used methylone, and $37.3 \%$ had first used mephedrone. Users have associated the new drugs with high risks and favored traditional drugs. A report on the occurrence and trends of new synthetic drugs in Sweden included participants who were 13-63 (median 20) years of age (31). The report described a widespread use of NPS in adolescents and young male adults (79\%), in incidents of drug intoxications reported by emergency departments and intensive care units. Of the 189 blood and urine samples that were examined in the laboratory, 156 (83\%) samples were found positive for NPS. More than 50 new synthetic drugs were detected. These included synthetic cannabinoid receptor agonists ("Spice"), piperazines, substituted phenethylamines, synthetic cathinones, hallucinogenic tryptamines, piperidines, opioid-related substances, ketamine and related substances, and $\gamma$-aminobutyric acid analogs. About half of the cases involved multiple drug intoxications, making it hard to link the clinical presentations with one specific substance.

\section{Synthetic Cannabinoids}

Synthetic cannabinoid users are usually men in their twenties, who use also other drugs. In a study of adult marijuana and tobacco users, the 42 respondents were male young adults, high school graduates, who also smoked tobacco and cannabis $(86 \%$ smoked cannabis on five or more days per week) (32). A very high proportion $(91 \%)$ were familiar with synthetic cannabinoid products, half (50\%) smoked them previously, and a minority (24\%) used them over the last month. Common reasons for use included expecting a strong "high" while avoiding detection by urine toxicology. The main side effects were difficulties in thinking, anxiety, dry mouth, and headache. Students also used synthetic cannabinoids out of curiosity and for feeling "high" (33). Eleven adolescents experienced euphoria and negative effects on memory, and nine reported negative mood changes (34).

Several informative surveys of synthetic cannabinoids use have involved college students. In a study of 852 college students in the United States, $69(8 \%)$ reported using the drugs at least once, and more common use in males and in the first or second year of college (35). A survey of students from a local health clinic and a US University found 9, 5, and 3\% lifetime, past-year, and past 30-day use of synthetic cannabinoids, respectively (36). In Rhode Island, 1,080 young (18-25 years old) participants were surveyed between January 2012 and July 2013, and 9\% reported use of synthetic cannabinoids in the last month. Synthetic cannabinoid users were predominantly males who did not attend school, smoked cigarettes, were binge alcohol drinkers, who used marijuana daily, as well as other recreational drugs (37). A survey of over 3,100 college students in North Carolina and Virginia showed that lifetime prevalence of synthetic cannabinoids was $7.6 \%$ at college entry and $6.6 \%$ first use during college (38). During the fourth year of college, lifetime synthetic cannabinoids use was reported by $17.0 \%$. The "Monitoring the Future study," a nationally representative sample of high school seniors between 2011 and 2013 included almost 12,000 participants of mean age 18 (39). In this sample, $10 \%$ reported any recent use and 3\% reported frequent use (over six times) of synthetic cannabinoids. Females were less likely to use synthetic cannabinoids, and going out 4-7 evenings per week increased likelihood of drug use.
Several factors were identified as increasing the risk for synthetic cannabinoid use, mainly high frequency of lifetime marijuana use, lifetime use of alcohol, cigarettes, and other illicit drugs. Among 396 patients entering residential treatment for Substance Use Disorder in the United States, 150 reported using synthetic cannabinoids in their lifetime. Motives for drug use were curiosity (91\%), "feeling good" or "getting high" (89\%), relaxation (71\%), and "getting high" while avoiding detection (71\%) (40). According to the 2009-2013 US National Survey of Drug Use and Health, the gender gap in the self-reported use of synthetic cannabinoids is smaller compared to other categories of NPS among non-institutionalized individuals aged 12-34 years old (41).

In an anonymous online survey among almost 15,000 participants in the UK, $2,513(17 \%)$ reported use of synthetic cannabinoids. Among them, 41\% reported use over the last 12 months (42). Almost all synthetic cannabinoids users (99\%) used natural cannabis at least once. Synthetic cannabinoids had a shorter effect and faster time to peak effect than natural cannabis. Most users (93\%) preferred natural cannabis to synthetic cannabinoids. Natural cannabis had greater pleasurable effects when "high" and allowed better function after use. Synthetic cannabinoids had negative effects such as hangover, and paranoia. In an anonymous follow-up online survey of drug use with over 22,000 respondents, use of synthetic cannabinoids was estimated as 30 times as more risky than natural cannabis (43).

In Australia, a sample of 316 synthetic cannabinoid users (77\% male, mean age 27 years) reported mean synthetic cannabinoid use of 6 months, 35\% reported weekly use and 7\% reported daily use (44). Reasons for first use included: curiosity (50\%), legality (39\%), availability (23\%), recreational effects (20\%), therapeutic effects $(9 \%)$, avoidance of detection by standard drug screening tests (8\%), and aid for the reduction or cessation of cannabis use. In a further study of over 1,100 students (mean age 14.9 years) from secondary schools in Australia, 2.4\% had ever used synthetic cannabis and $0.4 \%$ had used synthetic stimulants (45). Users also had an episode of binge drinking in the past 6 months, used tobacco and had higher levels of psychological distress and lower perceived self-efficacy to resist peer pressure than non-users, but did not differ from users of other illicit drugs.

\section{Comparative Epidemiology}

In a survey covering the years 2009 to 2012 in the United States, synthetic cathinone and synthetic cannabis exposures totaled 7,467 and 11,561, respectively (46), with increases in the use of both from 2009 to 2011. Synthetic cathinone use increased from none reported in 2009, to 298 in 2010, and 6,062 in 2011. By comparison, there were 14 reported synthetic cannabis exposures in $2009,2,821$ in 2010, and 6,255 in 2011. The number of those who were first-time exposed to synthetic cathinones was lower in $2012(1,007)$ than in $2011(2,027)$, while the number of firsttime exposures to synthetic cannabis was higher in $2012(2,389)$ than in $2011(1,888)$ possibly reflecting a shift from synthetic cathinone use toward the use of synthetic cannabinoids. Most exposures occurred in the Midwest and Southeastern US $(64.8 \%$ of synthetic cathinone and $58 \%$ of synthetic cannabis exposures). Males comprised $69 \%(n=5,153)$ of synthetic cathinone users and $74 \%(n=8,505)$ of synthetic cannabis users. Use of 
synthetic cathinones was highest in individuals 20-29 years of age $(n=2,943)$, while use of synthetic cannabinoids was highest for younger respondents, i.e., individuals 13-19 years of age $(n=5,349)$. A recent study involving 1,740 young adults recruited in US nightlife scenes (18-40 years old, mean age 26.4) showed that use of mephedrone and synthetic cannabinoids adults in US nightlife scenes is lower than in EU nightlife scenes (47). Specifically, $8.2 \%$ used synthetic cannabinoids, $1.1 \%$ used mephedrone. Gay and bisexual men reported more frequent use of mephedrone and more frequent use of synthetic cannabinoid use in individuals with Latin origin. In conclusion, synthetic cannabis emerged first with overall more reported exposures than synthetic cathinone. In 2012, synthetic cathinone abuse declined while synthetic cannabis abuse increased. Young men intentionally abusing synthetic cannabinoids via inhalation make up the majority of users.

\section{DRUG PHARMACOLOGY, CENTRAL EFFECTS, AND CLINICAL FEATURES}

\section{Synthetic Cathinones}

Synthetic cathinones represent a broad class of pharmacologically active compounds that induce numerous effects with different mechanisms of action. As such, each case of synthetic cathinone intoxication should be evaluated separately, at least until preclinical research will provide structure-activity relationships for each compound. Similar to the action of other psychostimulants, synthetic cathinones have an effect on plasma membrane transporters of the monoamine neurotransmitters, dopamine, norepinephrine, and serotonin (48). Mephedrone and methylone, but not MDPV, act as non-selective transporter agonists, thereby promoting release of all of these neurotransmitters. Conversely, MDPV acts as a potent blocker at catecholamine transporters with little effect at the serotonin transporter (48). Mephedrone or methylone administered to rats increase extracellular concentrations of dopamine and serotonin in the brain, similar to the effects of MDMA (48). Synthetic cathinones elicit locomotor stimulation in rodents similar to other psychstimulants. The enhanced dopamine transmission by synthetic cathinones presents a high potential for addiction that may result in adverse effects (49). See Table 1 for behavioral and pharmacological effects of synthetic cathinones in rodents.

\section{Acute and Chronic Side Effects}

Acute administration of low doses of synthetic cathinones produces euphoria and increases alertness, but high doses or chronic use can result in serious adverse effects, such as hallucinations, delirium, hyperthermia, and tachycardia (70). Repeated use of synthetic cathinones is associated with paranoia and hallucinations and some patients developed "excited delirium," a syndrome with symptoms of extreme agitation and violent behavior (70). The symptoms included dehydration, muscle damage and renal failure that may result in multi-organ failure and death. A 40-year-old male, who had no previous psychiatric history developed "excited delirium" after ingesting "bath salts" with psychosis and violence (71). Forty-three postmortem cases with detected
TABLE 1 | Studies investigating the behavioral effects of synthetic cathinones.

\begin{tabular}{|c|c|c|c|}
\hline Animals & $\begin{array}{l}\text { Synthetic cathinone } \\
\text { tested }\end{array}$ & Main findings & Reference \\
\hline Male ICR mice & $\begin{array}{l}\alpha \text {-PBP, } \alpha \text {-PPP, } \alpha \text {-PVP } \\
\text { MDPV } \\
\text { MEPH } \\
\text { Methylone } \\
\text { 3-FMC, 4-FMC, } \\
\text { 4-MePPP }\end{array}$ & $\begin{array}{l}\text { Motor stimulation } \\
\text { Decreased motor } \\
\text { coordination } \\
\text { Ataxia }\end{array}$ & $(50-52)$ \\
\hline $\begin{array}{l}\text { Male Sprague- } \\
\text { Dawley rats }\end{array}$ & $\begin{array}{l}\alpha-P V P \\
\text { MDPV } \\
\text { MEPH } \\
\text { Methcathinone } \\
\text { Methylone } \\
\text { R-MEPH, 4-MEC }\end{array}$ & $\begin{array}{l}\text { Significantly lower } \\
\text { ICSS threshold }\end{array}$ & $(53-55)$ \\
\hline $\begin{array}{l}\text { Male rats (Wistar, } \\
\text { Sprague-Dawley) }\end{array}$ & $\begin{array}{l}\alpha-P V T \\
\text { BMAPN } \\
\text { Buphedrone } \\
\text { MACHP } \\
\text { Methylone } \\
\text { MPDV } \\
\text { 4-MEC, 4-MePPP }\end{array}$ & $\begin{array}{l}\text { Sustain IVSA } \\
\text { behavior }\end{array}$ & $(56-63)$ \\
\hline $\begin{array}{l}\text { Male mice (CD-1, } \\
\text { ICR, C57BL/6J or } \\
\text { Swiss Webster) }\end{array}$ & $\begin{array}{l}\alpha \text {-PBP, } \alpha-P V P, \alpha-P V T \\
\text { BMAPN } \\
\text { Buphedrone } \\
\text { MACHP, MDPV } \\
\text { MEPH, MAOP } \\
\text { Methylone } \\
\text { PIPP }\end{array}$ & Induce CPP & $\begin{array}{l}(58-62 \\
64,65)\end{array}$ \\
\hline $\begin{array}{l}\text { Male and female } \\
\text { (MDPV) Sprague- } \\
\text { Dawley rats }\end{array}$ & $\begin{array}{l}\text { MDPV } \\
\text { R-MEPH } \\
\text { 4-MEC }\end{array}$ & Induce CPP & $(55,66-68)$ \\
\hline $\begin{array}{l}\text { Male Sprague- } \\
\text { Dawley rats }\end{array}$ & $\begin{array}{l}\alpha \text {-PBP, } \alpha \text {-PVP, } \alpha \text {-PVT } \\
\text { Methcathinone } \\
\text { Pentedrone } \\
\text { Pentylone } \\
\text { 3-FMC, 4-MePPP, } \\
\text { 4-MEC }\end{array}$ & $\begin{array}{l}\text { Substitute for the } \\
\text { discriminative } \\
\text { stimulus effects } \\
\text { of METH in a DD } \\
\text { paradigm }\end{array}$ & $\begin{array}{l}(61,65 \\
69,70)\end{array}$ \\
\hline
\end{tabular}

$\alpha$-PBP, $\alpha$-pyrrolidinopropiobutiophenone; $\alpha$-PVP, alpha-pyrrolidinovalerophenone $\alpha-P V T$, alpha-pyrrolidinopentiothiophenone; buphedrone, [2-(methylamino)-1phenylbutan-1-one, $\alpha$-methylamino-butyrophenone]; BMAPN, 2-(methylamino)1-(naphthalen-2-yl) propan-1-one; CPP, conditioned place preference; $D D$, drug discrimination; ICSS, intracranial self-stimulation; IVSA, intravenous selfadministration; MACHP, [1] 2-cyclohexyl-2-(methylamino)-1-phenylethanone; MAOP, [2] 2-(methylamino)-1-phenyloctan-1-one; MEPH, mephedrone; METH, metamphetamine; $M D P V$, methylenedioxyphyrovalerone; PIPP, $f$-piperidinopropiophenone; $R-M E P H$, R-mephedrone; 3-FMC, 3-fluoromethcathinone; 4-FMC, 4-fluoromethcathinone; 4-MEC, 4-methylethcathinone; 4-MePPP, 4-methyl-alpha-pyrrolidinopropiophenone.

synthetic cathinones had the following associated causes of death: driving under the influence of drugs (17 cases), domestic violence ( 2 cases), suicide ( 4 cases), overdose ( 12 cases), accidents (6 cases), drug-facilitated assault (1 case), and homicide (1 case) (72). The highest measured MDPV and methylone concentration was detected in a case of suicide by hanging and in a driver, respectively. A single case of death following methylone ingestion was reported in France (73).

Cardiovascular effects (tachycardia, hypertension) and hallucinations are the most recurrent medical complications of synthetic cathinone use. The most frequently reported unwanted 
clinical effects among cases reported to Texas poison centers during 2010-2011 were tachycardia (45.9\%), agitation (39.2\%), hypertension (21.0\%), hallucinations (17.7\%), and confusion (13.0\%) (74). A study of "bath-salt" exposure conducted in two poison centers in the United States found primarily neurological and cardiovascular effects. Drugs effects included agitation, combative behavior, tachycardia, hallucinations, paranoia, confusion, chest pain, myoclonus, hypertension, mydriasis, elevations in creatine phosphokinase, hypokalemia, blurred vision, and death (8). Signs of severe toxicity, such as hyperthermia, metabolic acidosis and prolonged rhabdomyolysis, indicative of high serotonergic activity, were also reported (75). A single case described cardiovascular manifestations, including tachycardia, hypertension, myocardial infarction, arrhythmias, and cardiac arrest (76).

\section{Seizures and Withdrawal}

Synthetic cathinone exposure has also resulted in many cases of seizures in the pediatric population. The American Association of Poison Control Centers database was used to examine synthetic cathinone exposures in children and youth below 20 years of age between 2010 and 2013 (77). There were 1,328 cases of pediatric synthetic cathinone exposures, of which 73 cases presented seizures complications: 37 (50.7\%) involved a single seizure, 29 (39.7\%) involved multiple seizures, and seven (9.6\%) developed epilepsy. Fever and acidosis were associated with single seizures, multiple seizures, and status epilepsy. There were no correlations between seizure activity and electrolyte abnormalities, hallucinations and/or delusions, tachycardia, or hypertension. The most commonly co-ingested substances were tetrahydrocannabinol, alcohol, and opioids. Finally, in Italy, a baby born to a woman who was a chronic consumer of 4-methylethcathinone showed symptoms of neonatal withdrawal syndrome (78). The newborn presented with increased jitteriness and irritability, high-pitched crying, limbs hypertonia and brisk tendon reflexes (78).

Regrettably, there is little information regarding the pharmacokinetics of synthetic cathinones in preclinical or clinical studies. Studies conducted so far have demonstrated that, upon systemic administration, synthetic cathinones are metabolized in several phase I compounds, some of which have been found to be substrates at monoamine transporters when assessed in vitro or to exert neurochemical actions in vivo $(79,80)$. The resulting metabolites can also partially undergo phase II metabolism (81). The presence of active metabolites could account, at least in part, for the diversified effects of these drugs.

\section{Synthetic Cannabinoids}

Unlike $\Delta$ 9-tetrahydrocannabinol (THC), synthetic cannabinoids are extremely potent, highly efficacious, full agonists of the cannabinoid receptors $(82,83)$, including CB1 receptors in the brain (84-89). There is substantial variability in the molecular constituents of different compounds, between assortment of the same product, and even within a package (20). In addition to synthetic cannabinoids, Spice drugs may contain preservatives, additives, fatty acids, amides, esters, the benzodiazepine phenazepam and $\mathrm{O}$-desmethyltramadol, an active metabolite of the opioid medication tramadol (90-92). Studies in rodents have indicated that most synthetic cannabinoids produce effects and toxicity that, overall, are similar to those of THC and include hypothermia, analgesia, hypo-locomotion, and akinesia (93). Yet, most effects are more potent and long-lasting than THC. See Table 2 for motor and reward-related behavioral effects of synthetic cannabinoids in rodents.

\section{Psychosis}

Cannabis use has potential for inducing psychosis [for recent reviews, see Ref. $(107,108)]$, and it would be reasonable to expect synthetic cannabinoids to have the same effect. Because of their high potency and the fact that synthetic cannabinoids act as full cannabinoid receptor agonists, even short or occasional use of these synthetic compounds can produce unwanted effects, such as insomnia, memory impairment, headaches, dizziness, and delusions. Moreover, unlike natural cannabis, synthetic cannabinoids contain no cannabidiol that may be protective against psychosis. Cannabidiol antagonizes the psychotomimetic and other psychotropic effects of THC although the mechanisms underlying its therapeutic effect are still not clear (109). Compared with natural cannabis, synthetic cannabinoids may cause more frequent and more severe unwanted negative effects, and may have high-risk for psychosis especially in young users (110). Case reports have documented psychosis $(111,112)$, mania (113), and suicidal ideations (114) in synthetic cannabinoid users.

\section{Brain Imaging Studies}

Although brain imaging studies have pointed to abnormalities in cerebral perfusion, deficits in brain volume and white-matter pathways (115), brain imaging has scarcely been applied to understand the neural correlates of synthetic cannabis use. A comparison of 20 male patients who had used synthetic cannabinoids with 20 healthy male controls indicated that drug users had smaller gray-matter volume in the thalamus and the cerebellum (116). A single case study of a 23-year-old patient reported severe withdrawal syndrome upon voluntary abstinence from "Spice Gold." Craving, affective symptoms and a range of somatic complaints were reported, but these were resolved after several days of monitored abstinence (117). In this patient, dopamine $\mathrm{D}_{2}$ and $\mathrm{D}_{3}$ receptor availability was $20 \%$ lower in the striatum and in extra-striatal regions with respect to healthy control participants, but returned to control values with detoxification. Brain imaging studies suggest that synthetic cannabinoid use can produce remarkable changes in the brain, but they are still preliminary, and the extent and duration of the neural sequelae of synthetic cannabinoid use remains to be determined.

\section{Effects on Driving}

Reports concerning driving under the influence of synthetic cannabinoids also reflect their impact on the nervous system. One report from the United States indicated that drivers under the influence of synthetic cannabinoids had slow and slurred speech, and poor coordination (118). A survey in Germany found behavioral deficits that were moderate except for worsening of paranoia in one case (119). The symptoms were similar to the effects of cannabinoid agonists but could also be a result of alcohol or other 
TABLE 2 | Studies investigating the behavioral effects of synthetic cannabinoids.

\begin{tabular}{|c|c|c|c|}
\hline Animals & Synthetic cannabinoid tested & Main findings & Reference \\
\hline Male mice (C57BL/6J, Swiss Webster) & $\begin{array}{l}\text { "Buzz" (5.4\% JWH-018) } \\
\text { JWH-018 } \\
\text { JWH-073 }\end{array}$ & $\begin{array}{l}\text { Induces a dose-related tetrad effects similar } \\
\text { to marijuana/THC }\end{array}$ & $(94,95)$ \\
\hline Male Swiss Webster/ICR mice & $\begin{array}{l}\text { AB-FUBINACA } \\
\text { AM-2201 } \\
\text { APINACANAKB-48 } \\
\text { JWH-018, JWH-073, JWH-200, JWH-203 } \\
\text { JWH-250 } \\
\text { PB-22 (QUPIC) } \\
\text { UR-144, XLR-11, 5F-PB-22 }\end{array}$ & $\begin{array}{l}\text { Decrease locomotor activity } \\
\text { Induce catalepsy }\end{array}$ & $(96-99)$ \\
\hline Male ICR mice & JWH-018 & $\begin{array}{l}\text { Significantly impairs sensorimotor functions } \\
\text { Induced convulsions, myoclonia and hyperreflexia } \\
\text { (at high doses) }\end{array}$ & $(14,99)$ \\
\hline Male Sprague-Dawley rats/C57BL/6 mice & JWH-018 & Sustains IVSA behavior & $(100)$ \\
\hline Male mice (ICR) & JWH-073, JWH-081, JWH-210 & Induce CPP & $(101)$ \\
\hline Male Sprague-Dawley rats & JWH-175 & Induces CPP & $(102)$ \\
\hline Male ND4 Swiss-Webster/ICR mice & $\begin{array}{l}\text { AB-CHMINACA } \\
\text { AB-PINACA } \\
\text { ADBICA } \\
\text { ADB-PINACA } \\
\text { FUBIMINA } \\
\text { JWH-018, JWH-122, JWH-210 } \\
\text { RCS-4, THJ-2201 }\end{array}$ & Fully substitute for $\mathrm{THC}$ in a DD paradigm & $(98,103)$ \\
\hline $\begin{array}{l}\text { Male and female (JWH-018) Sprague- } \\
\text { Dawley rats }\end{array}$ & $\begin{array}{l}\text { AB-FUBINACA } \\
\text { AM-2201 } \\
\text { APINACAVAKB-48 } \\
\text { JWH-018, JWH-073, JWH-200, JWH-203, } \\
\text { JWH-250 } \\
\text { PB-22/QUPIC } \\
\text { UR-144, XLR-11, 5F-PB-22 }\end{array}$ & Fully substitute for $\mathrm{THC}$ in a DD paradigm & $(96,97,104)$ \\
\hline Male adolescent rhesus monkeys & JWH-018 & $\begin{array}{l}\text { Shows discriminative stimulus effects; dose-dependently } \\
\text { increases drug-lever responding and decreased response } \\
\text { rate }\end{array}$ & $(105)$ \\
\hline Female and male adult rhesus monkeys & $\begin{array}{l}\mathrm{AM}-2201 \\
\mathrm{JWH} \\
\text { JWH }\end{array}$ & Substitute for the discriminative stimulus effects of $\Delta 9-\mathrm{THC}$ & $(106)$ \\
\hline \multicolumn{4}{|c|}{$\begin{array}{l}\text { AB-CHMINACA, N-[1-amino-3-methyl-oxobutan-2-yl]-1-[cyclohexylmethyl]-1H-indazole-3-carboxamide; AB-FUBINACA, N-(1-amino-3-methyl-1-oxobutan-2-yl)-1-(4-fluorobenzyl)- } \\
\text { 1H-indazole-3-carboxamide; AB-PINACA, N-(1-amino-3-methyl-1-oxobutan-2-yl)-1-pentyl-1H-indazole-3-carboxamide; ADBICA, N-(1-amino-3,3-dimethyl-1-oxobutan-2-yl)-1- } \\
\text { pentyl-1H-indole-3-carboxamide; ADB-PINACA, N-[1-(aminocarbonyl)-2,2-dimethylpropyl]-1-pentyl-1H-indazole-3-carboxamide; AM-2201, [1-(5-fluoropentyl)-1H-indol-3-yl]- } \\
\text { 1-naphthalen-methanone; APINACAIAKB-48, N-(1-adamantyl)-1-pentyl-1H-indazole-3-carboxamide; CPP, conditioned place preference; DD, drug discrimination; FUBIMINA, } \\
\text { (1-(5-fluoropentyl)-1H-benzo[d]imadazol-2-yl)(naphthalen-1-yl)methanone; ICSS, intracranial self-stimulation; IVSA, intravenous self-administration; JWH-018, 1-pentyl-3-(1-naphthoyl) } \\
\text { indole; JWH-073, naphthalen-1-yl-(1-butylindol-3-yl)methanone; JWH-081, 4-methoxynaphthalen-1-yl-(1-pentylindol-3-yl)methanone; JWH-175, (1-pentylindol-3-yl) naphthalen- } \\
\text { 1-ylmethane; JWH-200, [1-[2-(morpholinyl)ethyl]-1H-indol-3-yl]-1-naphthalenyl-methanone; JWH-203, (2-(2-chlorophenyl)-1-(1-phentyl)-1H-indol-3-yl)-methanone; JWH-210, } \\
\text { 4-ethylnaphthalen-1-yl-(1-pentylindol-3-yl)methanone; JWH-250, 2-(2-methoxyphenyl)-1-(1-pentylindol-3-yl)methanone; PB-22/QUPIC, quinolin-8-yl 1-pentyl-1H-indole-3- } \\
\text { carboxylate; RCS-4, 2-(4-methoxyphenyl)-1-(1-pentyl-indol-3-yl)methanone; THJ-2201, [1-(5-Fluoropentyl)-1H-indazol-3-yl](naphthalen-1-yl)methanone; UR-144, (1-pentylindol- } \\
\text { 3-yl)(2,2,3,3-tetramethylcyclopropyl)methanone; XLR-11, 5F-UR-144[1-(5-fluoro-pentyl)-1H-indol-3-yl](2,2,3,3-tetramethylcyclopropyl)methanone; 5F-PB-22, quinolin-8-yl-1-(5- } \\
\text { fluoropentyl)-1H-indole-3-carboxylate. }\end{array}$} \\
\hline
\end{tabular}

drugs detected by blood analysis. In several case reports sedating effects and impairment of fine motor skills were noted (120). In Poland, a single case showed that use of a synthetic-containing product caused effects and impairment similar to THC (121). Very few cases of synthetic cannabinoids were detected in the blood of drivers in Norway $(122,123)$.

\section{Health Hazards and Withdrawal}

Synthetic cannabinoid use has been associated with serious hazardous health effects on multiple systems, and with death
$(124,125)$. For example, among 3,572 calls related to synthetic cannabinoid use to call centers in the United States, 2,961 had a medical outcome, $11.3 \%$ callers had a major adverse effect, and 15 deaths were reported (126). The most common side effects are tachycardia, agitation, irritability, confusion, dizziness, drowsiness, hallucinations, delusions, hypertension, nausea, vomiting, vertigo and chest pain (127). Central nervous system effects range from headache to coma and included seizures, myoclonus, catatonic stupor, cerebral ischemia, and encephalopathy (128-131). Case reports have documented 
cardiac complications, ranging from chest pain (132) to myocardial infarction $(133,134)$, and cardiac arrest (135-137). Cases of acute kidney damage and renal failure following use of synthetic cannabinoids have also been reported (138). Dyspnea, rhabdomyolysis, diaphoresis, and hypokalemia, which are not commonly reported by cannabis users, have been associated with synthetic cannabinoid use (22). Case reports have also described respiratory depression following synthetic cannabinoids use (139) and, with chronic use, also pulmonary complications and pneumonia $(140,141)$. Rare cases of cannabinoid-induced hyperemesis syndrome were described which included repeated nausea and vomiting, abdominal pain, and a compulsion to take hot showers $(142,143)$.

Prolonged habitual use of synthetic cannabinoids resulted in withdrawal syndrome in case reports and in a study of 47 patients admitted to detoxification services $(144,145)$. The symptoms were similar to those of withdrawal from THC, including anxiety, myalgia, chills, anorexia, mood swings and tachycardia, but were more severe and did not seem to improve with the administration of THC $(144,146)$. The differences in presentation may reflect the inclusion of extraneous compounds, including amphetamine-like stimulants.

Noteworthy, differently from marijuana, while THC is metabolized to one active metabolite only, metabolism of new synthetic cannabinoids leads to the generation of pharmacologically active metabolites that remain biologically active and hold high affinity for the cannabinoid CB1 receptor $(147,148)$. As for synthetic cathinones, these active metabolites may prolong the psychotropic effects of the parent compound thus contributing to its toxicity.

\section{REGULATION AND LEGISLATION}

Responding to the rapid appearance of NPS with molecular structures that have not been covered by legislation, the governments of several countries have recognized the need for new mechanisms of control with accelerated ways to curtail the free sale and distribution of these substances (149). In Europe, since 1997 three levels of control were introduced: Early Warning System, risk assessments of newly emerged substances performed by the European Monitoring Centre for Drugs and Drug Addiction (EMCDDA) scientific committee and European Council decisions advocating new legislations (132). The possession, use, and synthesis of synthetic cathinones became subject to legal classification in Europe in 2010 (150) and in the United States in 2011 (149). Some countries such as Denmark, the UK, and Israel (151) opted for "temporary bans" of new psychoactive substances considered to pose danger to public health during which a risk assessment of a particular compound could be performed thus facilitating its subsequent inclusion into the Dangerous Drugs Ordinance. Other countries such as New Zealand, Ireland, Poland, and Romania (152) chose "pre-market approval" regulation regime for synthetic drugs that pose low health risk on the base of preclinical and clinical evidence. The effectiveness of these legal measures and regulations on the selling and marketing of the new psychoactive substances has still to be assessed.

\section{CONCLUSION}

Synthetic cathinones and synthetic cannabinoids became increasingly popular despite the potential harms associated with their use. Synthetic cathinones have similar clinical effects to amphetamines and MDMA whereas synthetic cannabinoids are high-potency, full agonists at cannabinoid receptors and induce THC-like effects, but more potent and enduring. Both classes of substances have various adverse health effects. Synthetic cathinones cause anxiety, agitation, panic, dysphoria, psychosis, and bizarre behavior whereas synthetic cannabinoids cause agitation, irritability, confusion, hallucinations, delusions, psychosis, and death (as well as other health problems illustrated above in the text and in Tables $\mathbf{1}$ and 2).

Chronic use of synthetic cathinones and synthetic cannabinoids results in adverse medical and psychiatric effects that seem to be higher than those induced by the natural parent compounds (i.e., cathinone and THC). In comparison with other known amphetamines, synthetic cathinones such as MEPH and MDPV exhibit a pharmacological profile that is more typical of methamphetamine and cocaine, respectively, while methylone shows a pharmacological profile that more closely resembles MDMA; yet, clinical toxicology of synthetic cathinones is not yet fully characterized. Synthetic cannabinoids show higher toxicity compared with natural cannabinoids, and their long-term effects are still to be investigated. In view of the increasing demand for these substances and their severe associated risks, more rigorous research on the effects of synthetic cathinones and synthetic cannabinoids is urgently required in order to understand their pharmacological effects and assist clinicians in managing adverse events.

These two classes of synthetic drugs are composed of pharmacologically diversified compounds with multiple mechanisms of action. Preclinical studies are urgently needed to elucidate their single action in both the brain and the periphery as well as their synergistic effects and long-term consequences. At clinical level, development of combined and integrated pharmacological and psychological approaches to treat intoxication symptoms is necessary. Treatment protocols currently available for the betterknown parental drugs need to be adapted to face with the increasing number of intoxications reported after the use of synthetic cathinones and synthetic cannabinoids.

\section{AUTHOR CONTRIBUTIONS}

AW and LF contributed substantially to the conception and design of the review. All the authors contributed to further drafts of the manuscript, critically revised, and approved the final version of the manuscript.

\section{FUNDING}

AW is supported by grants from the National Institute for Psychobiology, Israel, and the Israeli Anti-Drug Authority (IADA). EL received support from the Thomas P. and Katherine K. Pike Chair in Addiction Studies and the Marjorie M. Greene Trust. LF was supported by funds from "Joint Project 2012" from the University of Verona and Fondazione Banco di Sardegna, Italy. 


\section{REFERENCES}

1. Baumann MH, Solis E Jr, Watterson LR, Marusich JA, Fantegrossi WE, Wiley JL. Baths salts, spice, and related designer drugs: the science behind the headlines. J Neurosci (2014) 34(46):15150-8. doi:10.1523/JNEUROSCI. 3223-14.2014

2. Papaseit E, Farré M, Schifano F, Torrens M. Emerging drugs in Europe. Curr Opin Psychiatry (2014) 27(4):243-50. doi:10.1097/YCO. 0000000000000071

3. Zawilska JB, Wojcieszak J. Designer cathinones - an emerging class of novel recreational drugs. Forensic Sci Int (2013) 231(1-3):42-53. doi:10.1016/j. forsciint.2013.04.015

4. Zawilska JB. Mephedrone and other cathinones. Curr Opin Psychiatry (2014) 27(4):256-62. doi:10.1097/YCO.0000000000000066

5. Zawilska J. "Legal highs" - an emerging epidemic of novel psychoactive substances. Int Rev Neurobiol (2015) 120:273-300. doi:10.1016/bs.irn. 2015.02.009

6. Cottencin O, Rolland B, Karila L. New designer drugs (synthetic cannabinoids and synthetic cathinones): review of literature. Curr Pharm Des (2014) 20(25):4106-11. doi:10.2174/13816128113199990622

7. German CL, Fleckenstein AE, Hanson GR. Bath salts and synthetic cathinones: an emerging designer drug phenomenon. Life Sci (2014) 97(1):2-8. doi:10.1016/j.lfs.2013.07.023

8. Spiller HA, Ryan ML, Weston RG, Jansen J. Clinical experience with and analytical confirmation of "bath salts" and "legal highs" (synthetic cathinones) in the United States. Clin Toxicol (2011) 49(6):499-505. doi:10.3109/155636 50.2011 .590812

9. United Nations Office on Drugs and Crime (UNODC). World Drug Report. New York: United Nations Publication (2015). Sales No. E.15.XI.

10. European Monitoring Centre for Drugs and Drug Addiction (EMCDDA). New Psychoactive Substances in Europe (2015). An Update from the EU Early Warning System. Luxembourg: Publications Office of the European Union (2015).

11. Law R, Schier J, Martin C, Chang A, Wolkin A; Centers for Disease. Notes from the field: increase in reported adverse health effects related to synthetic cannabinoid use - United States, January-May 2015. MMWR Morb Mortal Wkly Rep (2015) 64(22):618-9.

12. Vandrey R, Johnson MW, Johnson PS, Khalil MA. Novel drugs of abuse: a snapshot of an evolving marketplace. Adolesc Psychiatry (2013) 3(2):123-34. doi: $10.2174 / 2210676611303020003$

13. United Nations Office on Drugs and Crime (UNODOC). World Drug Report. New York: United Nations Publication (2016). Sales No. E.16.XI.7.

14. De Luca MA, Bimpisidis Z, Melis M, Marti M, Caboni P, Valentini V, et al. Stimulation of in vivo dopamine transmission and intravenous self-administration in rats and mice by JWH-018, a spice cannabinoid. Neuropharmacology (2015) 99:705-14. doi:10.1016/j.neuropharm.2015. 08.041

15. Miliano C, Serpelloni G, Rimondo C, Mereu M, Marti M, De Luca MA. Neuropharmacology of new psychoactive substances (NPS): focus on the rewarding and reinforcing properties of cannabimimetics and amphetamine-like stimulants. Front Neurosci (2016) 10:153. doi:10.3389/fnins. 2016.00153

16. Baumann MH, Volkow ND. Abuse of new psychoactive substances (NPS): threats and solutions. Neuropsychopharmacology (2016) 41(3):663-5. doi:10.1038/npp.2015.260

17. Baumann MH, Ayestas MA Jr, Partilla JS, Sink JR, Shulgin AT, Daley PF, et al. The designer methcathinone analogs, mephedrone and methylone, are substrates for monoamine transporters in brain tissue. Neuropsychopharmacology (2012) 37:1192-203. doi:10.1038/npp.2011.304

18. Emerson TS, Cisek JE. Methcathinone: a Russian designer amphetamine infiltrates the rural midwest. Ann Emerg Med (1993) 22:1897-903. doi:10.1016/S0196-0644(05)80419-6

19. Karch SB. Cathinone neurotoxicity (the "3Ms"). Curr Neuropharmacol (2015) 13(1):21-5. doi:10.2174/1570159X13666141210225009

20. European Monitoring Centre for Drugs and Drug Addiction (EMCDDA). Thematic Paper - Understanding the 'Spice' Phenomenon. Luxembourg: Office for Official Publications of the European Communities (2009).
21. Macher R, Burke TW, Owen SS. Synthetic Marijuana. FBI Law Enforcement Bulletin. (2012). Available from: http://leb.fbi.gov/2012/may/ synthetic-marijuana

22. Mills B, Yepes A, Nugent K. Synthetic cannabinoids. Am J Med Sci (2015) 350(1):59-62. doi:10.1097/MAJ.0000000000000466

23. Seely K, Lapoint J, Moran JH, Fattore L. Spice drugs are more than harmless herbal blends: a review of the pharmacology and toxicology of synthetic cannabinoids. Prog Neuropsychopharmacol Biol Psychiatry (2012) 39(2):234-43. doi:10.1016/j.pnpbp.2012.04.017

24. Makriyannis A, Deng H. Cannabimimetic Indole Derivates. United States patent US 20080090871A (2007).

25. Nakajima M, al'Absi M, Dokam A, Alsoofi M, Khalil NS, Al Habori M. Gender differences in patterns and correlates of khat and tobacco use. Nicotine Tob Res (2013) 15(6):1130-5. doi:10.1093/ntr/nts257

26. Stevenson M, Fitzgerald J, Banwell C. Chewing as a social act: cultural displacement and khat consumption in the East African communities of Melbourne Drug Alcohol Rev (1996) 15(1):73-82. doi:10.1080/09595239600185691

27. Johnson S, Johnson MW. Investigation of "bath salts" use patterns within an online sample of users in the United States. J Psychoactive Drugs (2014) 46(5):369-78. doi:10.1080/02791072.2014.962717

28. Péterfi A, Tarján A, Horváth GC, Csesztregi T, Nyírády A. Changes in patterns of injecting drug use in Hungary: a shift to synthetic cathinones. Drug Test Anal (2014) 6(7-8):825-31. doi:10.1002/dta.1625

29. Dargan PI, Albert S, Wood DM. Mephedrone use and associated adverse effects in school and college/university students before the UK legislation change. QJM (2010) 103(11):875-9. doi:10.1093/qjmed/hcq134

30. Sande M. Characteristics of the use of 3-MMC and other new psychoactive drugs in Slovenia and the perceived problems experienced by users. Int J Drug Policy (2016) 27:65-73. doi:10.1016/j.drugpo.2015.03.005

31. Helander A, Bäckberg M, Hultén P, Al-Saffar Y, Beck O. Detection of new psychoactive substance use among emergency room patients: results from the Swedish STRIDA project. Forensic Sci Int (2014) 243:23-9. doi:10.1016/j. forsciint.2014.02.022

32. Gunderson EW, Haughey HM, Ait-Daoud N, Joshi AS, Hart CL. "Spice" and "K2" herbal highs: a case series and systematic review of the clinical effects and biopsychosocial implications of synthetic cannabinoid use in humans. Am J Addict (2012) 21(4):320-6. doi:10.1111/j.1521-0391.2012. 00240.x

33. Vidourek RA, King KA, Burbage ML. Reasons for synthetic THC use among college students. J Drug Educ (2013) 43(4):353-63. doi:10.2190/DE.43.4.d

34. Castellanos D, Thornton G. Synthetic cannabinoid use: recognition and management. J Psychiatr Pract (2012) 18(2):86-93. doi:10.1097/01. pra.0000413274.09305.9c

35. Hu X, Primack BA, Barnett TE, Cook RL. College students and use of K2: an emerging drug of abuse in young persons. Subst Abuse Treat Prev Policy (2011) 6:16. doi:10.1186/1747-597X-6-16

36. Gutierrez KM, Cooper TV. Investigating correlates of synthetic marijuana and Salvia use in light and intermittent smokers and college students in a predominantly Hispanic sample. Exp Clin Psychopharmacol (2014) 22(6):524-9. doi:10.1037/a0038014

37. Caviness CM, Tzilos G, Anderson BJ, Stein MD. Synthetic cannabinoids: use and predictors in a community sample of young adults. Subst Abus (2015) 36(3):368-73. doi:10.1080/08897077.2014.959151

38. Egan KL, Suerken CK, Reboussin BA, Spangler J, Wagoner KG, Sutfin EL, et al. K2 and spice use among a cohort of college students in southeast region of the USA. Am J Drug Alcohol Abuse (2015) 1:1-6. doi:10.3109/00 952990.2015.1043438

39. Palamar JJ, Acosta P. Synthetic cannabinoid use in a nationally representative sample of US high school seniors. Drug Alcohol Depend (2015) 149:194-202. doi:10.1016/j.drugalcdep.2015.01.044

40. Bonar EE, Ashrafioun L, Ilgen MA. Synthetic cannabinoid use among patients in residential substance use disorder treatment: prevalence, motives, and correlates. Drug Alcohol Depend (2014) 143:268-71. doi:10.1016/j. drugalcdep.2014.07.009

41. Palamar JJ, Martins SS, Su MK, Ompad DC. Self-reported use of novel psychoactive substances in a US nationally representative survey: prevalence, correlates, and a call for new survey methods to prevent underre- 
porting. Drug Alcohol Depend (2015) 156:112-9. doi:10.1016/j.drugalcdep. 2015.08.028

42. Winstock AR, Barratt MJ. Synthetic cannabis: a comparison of patterns of use and effect profile with natural cannabis in a large global sample. Drug Alcohol Depend (2013) 131(1-2):106-11. doi:10.1016/j.drugalcdep. 2012.12.011

43. Winstock A, Lynskey M, Borschmann R, Waldron J. Risk of emergency medical treatment following consumption of cannabis or synthetic cannabinoids in a large global sample. J Psychopharmacol (2015) 29(6):698-703. doi:10.1177/0269881115574493

44. Barratt MJ, Cakic V, Lenton S. Patterns of synthetic cannabinoid use in Australia.DrugAlcoholRev(2013)32(2):141-6.doi:10.1111/j.1465-3362.2012. 00519.x

45. Champion KE, Teesson M, Newton NC. Patterns and correlates of new psychoactive substance use in a sample of Australian high school students. Drug Alcohol Rev (2016) 35(3):338-44. doi:10.1111/dar.12312

46. Wood KE. Exposure to bath salts and synthetic tetrahydrocannabinol from 2009 to 2012 in the United States. JPediatr (2013) 163(1):213-6. doi:10.1016/j.jpeds.2012.12.056

47. Baumann MH, Partilla JS, Lehner KR. Psychoactive "bath salts": not so soothing. Eur J Pharmacol (2013) 698(1-3):1-5. doi:10.1016/j.ejphar.2012. 11.020

48. Kelly BC, Wells BE, Pawson M, LeClair A, Parsons JT, Golub SA. Novel psychoactive drug use among younger adults involved in US nightlife scenes. Drug Alcohol Rev (2013) 32(6):588-93. doi:10.1111/dar.12058

49. Marusich JA, Grant KR, Blough BE, Wiley JL. Effects of synthetic cathinones contained in "bath salts" on motor behavior and a functional observational battery in mice. Neurotoxicology (2012) 33(5):1305-13. doi:10.1016/j. neuro.2012.08.003

50. Marusich JA, Antonazzo KR, Wiley JL, Blough BE, Partilla JS, Baumann MH. Pharmacology of novel synthetic stimulants structurally related to the "bath salts" constituent 3,4-methylenedioxypyrovalerone (MDPV). Neuropharmacology (2014) 87:206-13. doi:10.1016/j.neuropharm. 2014.02.016

51. Saha K, Partilla JS, Lehner KR, Seddik A, Stockner T, Holy M, et al. 'Secondgeneration' mephedrone analogs, 4-MEC and 4-MePPP, differentially affect monoamine transporter function. Neuropsychopharmacology (2015) 40(6):1321-31. doi:10.1038/npp.2014.325

52. Watterson LR, Burrows BT, Hernandez RD, Moore KN, Grabenauer M, Marusich JA, et al. Effects of $\alpha$-pyrrolidinopentiophenone and 4-methyl-N-ethylcathinone, two synthetic cathinones commonly found in second-generation "bath salts," on intracranial self-stimulation thresholds in rats. Int J Neuropsychopharmacol (2014) 18(1):yu014. doi:10.1093/ijnp/ pyu014

53. Bonano JS, Glennon RA, De Felice LJ, Banks ML, Negus SS. Abuse-related and abuse-limiting effects of methcathinone and the synthetic "bath salts" cathinone analogs methylenedioxypyrovalerone (MDPV), methylone, and mephedrone on intracranial self-stimulation in rats. Psychopharmacology (2014) 231(1):199-207. doi:10.1007/s00213-013-3223-5

54. Gregg RA, Baumann MH, Partilla JS, Bonano JS, Vouga A, Tallarida CS, et al. Stereochemistry of mephedrone neuropharmacology: enantiomer-specific behavioural and neurochemical effects in rats. Br J Pharmacol (2015) 172(3):883-94. doi:10.1111/bph.12951

55. Watterson LR, Hood L, Sewalia K, Tomek SE, Yahn S, Johnson CT, et al. The reinforcing and rewarding effects of methylone, a synthetic cathinone commonly found in "bath salts". J Addict Res Ther (2012) (Suppl 9):002. doi:10.4172/2155-6105.S9-002

56. Watterson LR, Kufahl PR, Nemirovsky NE, Sewalia K, Grabenauer M, Thomas BF, et al. Potent rewarding and reinforcing effects of the synthetic cathinone 3,4-methylenedioxypyrovalerone (MDPV). Addict Biol (2014) 19(2):165-74. doi:10.1111/j.1369-1600.2012.00474.x

57. Botanas CJ, Yoon SS, de la Peña JB, Dela Peña IJ, Kim M, Woo T, et al. The abuse potential of $\alpha$-piperidinopropiophenone (PIPP) and $\alpha$-piperidinopentiothiophenone (PIVT), two new synthetic cathinones with piperidine ring substituent. Biomol Ther (Seoul) (2017) 25(2):122-9. doi:10.4062/ biomolther.2016.241

58. Botanas CJ, Yoon SS, de la Peña JB, Dela Peña IJ, Kim M, Woo T, et al. The abuse potential of two novel synthetic cathinones with modification on the alpha-carbon position, 2-cyclohexyl-2-(methylamino)-1-phenylethanone
(MACHP) and 2-(methylamino)-1-phenyloctan-1-one (MAOP), and their effects on dopaminergic activity. Pharmacol Biochem Behav (2017) 153:160-7. doi:10.1016/j.pbb.2016.12.017

59. Botanas CJ, Yoon SS, de la Peña JB, Dela Peña IJ, Kim M, Woo T, et al. A novel synthetic cathinone, 2-(methylamino)-1-(naphthalen-2-yl) propan-1-one (BMAPN), produced rewarding effects and altered striatal dopamine-related gene expression in mice. Behav Brain Res (2017) 317:494-501. doi:10.1016/j. bbr.2016.10.016

60. Cheong JH, Choi MJ, Jang CG, Lee YS, Lee S, Kim HJ, et al. Behavioral evidence for the abuse potential of the novel synthetic cathinone alpha-pyrrolidinopentiothiophenone (PVT) in rodents. Psychopharmacology (2017) 234(5):857-67. doi:10.1007/s00213-017-4526-8

61. Oh JH, Hwang JY, Hong SI, Ma SX, Seo JY, Lee SY, et al. The new designer drug buphedrone produces rewarding properties via dopamine D1 receptor activation. Addict Biol (2016). doi:10.1111/adb.12472

62. Huskinson SL, Naylor JE, Townsend EA, Rowlett JK, Blough BE, Freeman KB. Self-administration and behavioral economics of secondgeneration synthetic cathinones in male rats. Psychopharmacology (2017) 234(4):589-98. doi:10.1007/s00213-016-4492-6

63. Karlsson L, Andersson M, Kronstrand R, Kugelberg FC. Mephedrone, methylone and 3,4-methylenedioxypyrovalerone (MDPV) induce conditioned place preference in mice. Basic Clin Pharmacol Toxicol (2014) 115(5):411-6. doi:10.1111/bcpt.12253

64. Gatch MB, Rutledge MA, Forster MJ. Discriminative and locomotor effects of five synthetic cathinones in rats and mice. Psychopharmacology (2015) 232(7):1197-205. doi:10.1007/s00213-014-3755-3

65. Gregg RA, Hicks C, Nayak SU, Tallarida CS, Nucero P, Smith GR, et al. Synthetic cathinone MDPV downregulates glutamate transporter subtype I (GLT-1) and produces rewarding and locomotor-activating effects that are reduced by a GLT-1 activator. Neuropharmacology (2016) 108:111-9. doi:10.1016/j.neuropharm.2016.04.014

66. Xu P, Qiu Y, Zhang Y, Bai Y, Xu P, Liu Y, et al. The effects of 4-methylethcathinone on conditioned place preference, locomotor sensitization, and anxiety-like behavior: a comparison with methamphetamine. Int J Neuropsychopharmacol (2016) 19(4):yv120. doi:10.1093/ijnp/ pyv120

67. King HE, Wakeford A, Taylor W, Wetzell B, Rice KC, Riley AL. Sex differences in 3,4-methylenedioxypyrovalerone (MDPV)-induced taste avoidance and place preferences. Pharmacol Biochem Behav (2015) 137:16-22. doi:10.1016/j.pbb.2015.07.013

68. Naylor JE, Freeman KB, Blough BE, Woolverton WL, Huskinson SL. Discriminative-stimulus effects of second generation synthetic cathinones in methamphetamine-trained rats. Drug Alcohol Depend (2015) 149:280-4. doi:10.1016/j.drugalcdep.2015.02.002

69. Gatch MB, Dolan SB, Forster MJ. Comparative behavioral pharmacology of three pyrrolidine-containing synthetic cathinone derivatives. JPharmacol Exp Ther (2015) 354(2):103-10. doi:10.1124/jpet.115.223586

70. Penders TM, Gestring RE, Vilensky DA. Excited delirium following use of synthetic cathinones (bath salts). Gen Hosp Psychiatry (2012) 34(6):647-50. doi:10.1016/j.genhosppsych.2012.06.005

71. John ME, Thomas-Rozea C, Hahn D. Bath salts abuse leading to new onset psychosis and potential for violence. Clin Schizophr Relat Psychoses (2014) 20:1-14. doi:10.3371/CSRP.JORO.061314

72. Marinetti LJ, Antonides HM. Analysis of synthetic cathinones commonly found in bath salts in human performance and postmortem toxicology: method development, drug distribution and interpretation of results. J Anal Toxicol (2013) 37(3):135-46. doi:10.1093/jat/bks136

73. Barrios L, Grison-Hernando H, Boels D, Bouquie R, Monteil-Ganiere C, Clement R. Death following ingestion of methylone. Int J Legal Med (2016) 130(2):381-5. doi:10.1007/s00414-015-1212-4

74. Forrester MB. Synthetic cathinone exposures reported to Texas poison centers. Am J Drug Alcohol Abuse (2012) 38(6):609-15. doi:10.3109/00952 990.2012 .677890

75. Paillet-Loilier M, Cesbron A, Le Boisselier R, Bourgine J, Debruyne D. Emerging drugs of abuse: current perspectives on substituted cathinones. Subst Abuse Rehabil (2014) 5:37-52. doi:10.2147/SAR.S37257

76. Sivagnanam K, Chaudari D, Lopez P, Sutherland ME, Ramu VK. "Bath salts" induced severe reversible cardiomyopathy. Am J Case Rep (2013) 14:288-91. doi:10.12659/AJCR.889381 
77. Tekulve K, Alexander A, Tormoehlen L. Seizures associated with synthetic cathinone exposures in the pediatric population. Pediatr Neurol (2014) 51(1):67-70. doi:10.1016/j.pediatrneurol.2014.03.003

78. Pichini S, Rotolo MC, García J, Girona N, Leal L, García-Algar O, et al. Neonatal withdrawal syndrome after chronic maternal consumption of 4-methylethcathinone. Forensic Sci Int (2014) 245:e33-5. doi:10.1016/j. forsciint.2014.10.027

79. Mayer FP, Wimmer L, Dillon-Carter O, Partilla JS, Burchardt NV, Mihovilovic MD, et al. Phase I metabolites of mephedrone display biological activity as substrates at monoamine transporters. Br JPharmacol (2016) 173(17):2657-68. doi:10.1111/bph.13547

80. Baumann MH, Bukhari MO, Lehner KR, Anizan S, Rice KC, Concheiro M, et al. Neuropharmacology of 3,4-methylenedioxypyrovalerone (MDPV), its metabolites, and related analogs. Curr Top Behav Neurosci (2017) 32:93-117. doi:10.1007/7854_2016_53

81. Anizan S, Concheiro M, Lehner KR, Bukhari MO, Suzuki M, Rice KC, et al. Linear pharmacokinetics of 3,4-methylenedioxypyrovalerone (MDPV) and its metabolites in the rat: relationship to pharmacodynamic effects. Addict Biol (2016) 21(2):339-47. doi:10.1111/adb.12201

82. Spaderna M, Addy PH, D'Souza DC. Spicing things up: synthetic cannabinoids. Psychopharmacology (2013) 228(4):525-40. doi:10.1007/ s00213-013-3188-4

83. Fantegrossi WE, Moran JH, Radominska-Pandya A, Prather PL. Distinct pharmacology and metabolism of K2 synthetic cannabinoids compared to $\Delta$ (9)-THC: mechanism underlying greater toxicity? Life Sci (2014) 97(1):45-54. doi:10.1016/j.lfs.2013.09.017

84. Atwood BK, Huffman J, Straiker A, Mackie K. JWH018, a common constituent of 'spice' herbal blends, is a potent and efficacious cannabinoid CB receptor agonist. Br JPharmacol (2010) 160:585-93. doi:10.1111/j.1476-5381.2009.00582.x

85. Atwood BK, Lee D, Straiker A, Widlanski TS, Mackie K. CP47,497-C8 and JWH073, commonly found in 'spice' herbal blends, are potent and efficacious CB(1) cannabinoid receptor agonists. Eur J Pharmacol (2011) 659:139-45. doi:10.1016/j.ejphar.2011.01.066

86. Huffman JW, Padgett LW. Recent developments in the medicinal chemistry of cannabimimetic indoles, pyrroles and indenes. Curr Med Chem (2005) 12:1395-411. doi:10.2174/0929867054020864

87. Huffman JW, Zengin G, Wu MJ, Lu J, Hynd G, Bushell K, et al. Structureactivity relationships for 1-alkyl-3-(1-naphthoyl)indoles at the cannabinoid $\mathrm{CB}(1)$ and $\mathrm{CB}(2)$ receptors: steric and electronic effects of naphthoyl substituents. New highly selective CB(2) receptor agonists. Bioorg Med Chem (2005) 13:89-112. doi:10.1016/j.bmc.2004.09.050

88. Lindigkeit R, Boehme A, Eiserloh I, Luebbecke M, Wiggermann M, Ernst L, et al. Spice: a never ending story? Forensic Sci Int (2009) 191:58-63. doi:10.1016/j.forsciint.2009.06.008

89. Marriott KS, Huffman JW. Recent advances in the development of selective ligands for the cannabinoid $\mathrm{CB}(2)$ receptor. Curr Top Med Chem (2008) 8:187-204. doi:10.2174/156802608783498014

90. Brown K. New Zealand bans synthetic cannabinoids. BMJ (2011) 343:d5395. doi:10.1136/bmj.d5395

91. Dresen S, Ferreiros N, Putz M, Westphal F, Zimmermann R, Auwarter V. Monitoring of herbal mixtures potentially containing synthetic cannabinoids as psychoactive compounds. J Mass Spectrom (2010) 45:1186-94. doi:10.1002/jms.1811

92. Zuba D, Byrska B, Maciow M. Comparison of "herbal highs" composition. Anal Bioanal Chem (2011) 400:119-26. doi:10.1007/s00216-011-4743-7

93. Wiebelhaus JM, Poklis JL, Poklis A, Vann RE, Lichtman AH, Wise LE. Inhalation exposure to smoke from synthetic "marijuana" produces potent cannabimimetic effects in mice. Drug Alcohol Depend (2012) 126(3):316-23. doi:10.1016/j.drugalcdep.2012.05.034

94. Marshell R, Kearney-Ramos T, Brents LK, Hyatt WS, Tai S, Prather PL, et al. In vivo effects of synthetic cannabinoids JWH-018 and JWH-073 and phytocannabinoid $\triangle 9$-THC in mice: inhalation versus intraperitoneal injection. Pharmacol Biochem Behav (2014) 124:40-7. doi:10.1016/j. pbb.2014.05.010

95. Gatch MB, Forster MJ. $\Delta$ 9-Tetrahydrocannabinol-like discriminative stimulus effects of compounds commonly found in K2/Spice. Behav Pharmacol (2014) 25(8):750-7. doi:10.1097/FBP.0000000000000093
96. Gatch MB, Forster MJ. $\Delta$ 9-Tetrahydrocannabinol-like effects of novel synthetic cannabinoids found on the gray market. Behav Pharmacol (2015) 26(5):460-8. doi:10.1097/FBP.0000000000000150

97. Wiley JL, Marusich JA, Lefever TW, Antonazzo KR, Wallgren MT, Cortes RA, et al. AB-CHMINACA, AB-PINACA, and FUBIMINA: affinity and potency of novel synthetic cannabinoids in producing $\Delta 9$-tetrahydrocannabinol-like effects in mice. J Pharmacol Exp Ther (2015) 354(3):328-39. doi:10.1124/ jpet.115.225326

98. Vigolo A, Ossato A, Trapella C, Vincenzi F, Rimondo C, Seri C, et al. Novel halogenated derivates of JWH-018: behavioral and binding studies in mice. Neuropharmacology (2015) 95:68-82. doi:10.1016/j.neuropharm. 2015.02.008

99. Ossato A, Vigolo A, Trapella C, Seri C, Rimondo C, Serpelloni G, et al. JWH-018 impairs sensorimotor functions in mice. Neuroscience (2015) 300:174-88. doi:10.1016/j.neuroscience.2015.05.021

100. Cha HJ, Lee KW, Song MJ, Hyeon YJ, Hwang JY, Jang CG, et al. Dependence potential of the synthetic cannabinoids JWH-073, JWH-081, and JWH-210: in vivo and in vitro approaches. Biomol Ther (Seoul) (2014) 22(4):363-9. doi:10.4062/biomolther.2014.039

101. Tampus R, Yoon SS, de la Peña JB, Botanas CJ, Kim HJ, Seo JW, et al. Assessment of the abuse liability of synthetic cannabinoid agonists JWH030, JWH-175, and JWH-176. Biomol Ther (Seoul) (2015) 23(6):590-6. doi:10.4062/biomolther.2015.120

102. Gatch MB, Forster MJ. $\Delta(9)$-Tetrahydrocannabinol-like effects of novel synthetic cannabinoids in mice and rats. Psychopharmacology (2016) 233(10):1901-10. doi:10.1007/s00213-016-4237-6

103. Wiley JL, Lefever TW, Marusich JA, Craft RM. Comparison of the discriminative stimulus and response rate effects of $\Delta 9$-tetrahydrocannabinol and synthetic cannabinoids in female and male rats. Drug Alcohol Depend (2017) 172:51-9. doi:10.1016/j.drugalcdep.2016

104. Rodriguez JS, McMahon LR. JWH-018 in rhesus monkeys: differential antagonism of discriminative stimulus, rate-decreasing, and hypothermic effects. Eur J Pharmacol (2014) 740:151-9. doi:10.1016/j.ejphar.2014. 06.023

105. Hruba L, McMahon LR. Apparent affinity estimates and reversal of the effects of synthetic cannabinoids AM-2201, CP-47,497, JWH-122, and JWH-250 by rimonabant in rhesus monkeys. J Pharmacol Exp Ther (2017) 362(2):278-86. doi:10.1124/jpet.117.240572

106. Wilkinson ST, Radhakrishnan R, D'Souza DC. Impact of cannabis use on the development of psychotic disorders. Curr Addict Rep (2014) 1(2):115-28. doi:10.1007/s40429-014-0018-7

107. Radhakrishnan R, Wilkinson ST, D'Souza DC. Gone to pot - a review of the association between cannabis and psychosis. Front Psychiatry (2014) 5:54. doi:10.3389/fpsyt.2014.00054

108. van Amsterdam J, Brunt T, van den Brink W. The adverse health effects of synthetic cannabinoids with emphasis on psychosis-like effects. J Psychopharmacol (2015) 29(3):254-63. doi:10.1177/0269881114565142

109. Campos AC, Moreira FA, Gomes FV, Del Bel EA, Guimarães FS. Multiple mechanisms involved in the large-spectrum therapeutic potential of cannabidiol in psychiatric disorders. Philos Trans R Soc Lond B Biol Sci (2012) 367:3364-78. doi:10.1098/rstb.2011.0389

110. Fattore L. Synthetic cannabinoids-further evidence supporting the relationship between cannabinoids and psychosis. Biol Psych (2016) 79:539-48. doi:10.1016/j.biopsych.2016.02.001

111. Celofiga A, Koprivsek J, Klavz J. Use of synthetic cannabinoids in patients with psychotic disorders: case series. J Dual Diagn (2014) 10(3):168-73. doi:10.1080/15504263.2014.929364

112. Meijer KA, Russo RR, Adhvaryu DV. Smoking synthetic marijuana leads to self-mutilation requiring bilateral amputations. Orthopedics (2014) 37(4):e391-4. doi:10.3928/01477447-20140401-62

113. Ustundag MF, Ozhan Ibis E, Yucel A, Ozcan H. Synthetic cannabisinduced mania. Case Rep Psychiatry (2015) 2015:310930. doi:10.1155/2015/ 310930

114. Thomas S, Bliss S, Malik M. Suicidal ideation and self-harm following K2 use. J Okla State Med Assoc (2012) 105(11):430-3.

115. Lubman DI, Cheetham A, Yücel M. Cannabis and adolescent brain development. Pharmacol Ther (2015) 148:1-16. doi:10.1016/j.pharmthera. 2014.11.009 
116. Nurmedov S, Metin B, Ekmen S, Noyan O, Yilmaz O, Darcin A, et al. Thalamic and cerebellar gray matter volume reduction in synthetic cannabinoids users. Eur Addict Res (2015) 21(6):315-20. doi:10.1159/000430437

117. Rominger A, Cumming P, Xiong G, Koller G, Förster S, Zwergal A, et al. Effects of acute detoxification of the herbal blend 'spice gold' on dopamine D2/3 receptor availability: a [18F]fallypride PET study. Eur Neuropsychopharmacol (2013) 23(11):1606-10. doi:10.1016/j.euroneuro.2013.01.009

118. Yeakel JK, Logan BK. Blood synthetic cannabinoid concentrations in cases of suspected impaired driving. J Anal Toxicol (2013) 37(8):547-51. doi:10.1093/ jat/bkt065

119. Jaenicke NJ, Pogoda W, Paulke A, Wunder C, Toennes SW. Retrospective analysis of synthetic cannabinoids in serum samples-epidemiology and consumption patterns. Forensic Sci Int (2014) 242:81-7. doi:10.1016/j. forsciint.2014.06.010

120. Musshoff F, Madea B, Kernbach-Wighton G, Bicker W, Kneisel S, Hutter $M$, et al. Driving under the influence of synthetic cannabinoids ("spice"): a case series. Int J Legal Med (2014) 128(1):59-64. doi:10.1007/ s00414-013-0864-1

121. Adamowicz P, Lechowicz W. The influence of synthetic cannabinoid UR-144 on human psychomotor performance - a case report demonstrating road traffic risks. Traffic Inj Prev (2015) 20:1-6. doi:10.1080/15389588.2015.101 8990

122. Tuv SS, Krabseth H, Karinen R, Olsen KM, Øiestad EL, Vindenes V. Prevalence of synthetic cannabinoids in blood samples from Norwegian drivers suspected of impaired driving during a seven weeks period. Accid Anal Prev (2014) 62:26-31. doi:10.1016/j.aap.2013.09.009

123. Karinen R, Tuv SS, Øiestad EL, Vindenes V. Concentrations of APINACA, 5F-APINACA, UR-144 and its degradant product in blood samples from six impaired drivers compared to previous reported concentrations of other synthetic cannabinoids. Forensic Sci Int (2015) 246:98-103. doi:10.1016/j. forsciint.2014.11.012

124. Trecki J, Gerona RR, Schwartz MD. Synthetic cannabinoid-related illnesses and deaths. N Engl J Med (2015) 373(2):103-7. doi:10.1056/ NEJMp1505328

125. Bonnet U, Mahler H. Synthetic cannabinoids: spread, addiction biology \& current perspective of personal health hazard. Fortschr Neurol Psychiatr (2015) 83(4):221-31. doi:10.1055/s-0034-1399307

126. Shanks KG, Winston D, Heidingsfelder J, Behonick G. Case reports of synthetic cannabinoid XLR-11 associated fatalities. Forensic Sci Int (2015) 252:e6-9. doi:10.1016/j.forsciint.2015.04.021

127. Besli GE, Ikiz MA, Yildirim S, Saltik S. Synthetic cannabinoid abuse in adolescents: a case series. Emerg Med (2015) 49(5):644-50. doi:10.1016/j. jemermed.2015.06.053

128. Bernson-Leung ME, Leung LY, Kumar S. Synthetic cannabis and acute ischemic stroke. J Stroke Cerebrovasc Dis (2014) 23(5):1239-41. doi:10.1016/j. jstrokecerebrovasdis.2013.07.030

129. Louh IK, Freeman WD. A 'spicy' encephalopathy: synthetic cannabinoids as cause of encephalopathy and seizure. Crit Care (2014) 18(5):553. doi:10.1186/ s13054-014-0553-6

130. Gugelmann H, Gerona R, Li C, Tsutaoka B, Olson KR, Lung D. 'Crazy monkey' poisons man and dog: human and canine seizures due to PB-22, a novel synthetic cannabinoid. Clin Toxicol (2014) 52(6):635-8. doi:10.3109/ 15563650.2014 .925562

131. Takematsu M, Hoffman RS, Nelson LS, Schechter JM, Moran JH, Wiener SW. A case of acute cerebral ischemia following inhalation of a synthetic cannabinoid. Clin Toxicol (2014) 52(9):973-5. doi:10.3109/ 15563650.2014 .958614

132. Atik SU, Dedeoğlu R, Varol F, Çam H, Eroğlu AG, Saltık L. Cardiovascular side effects related with use of synthetic cannabinoids "bonsai" two case reports. Turk Pediatri Ars (2015) 50(1):61-4. doi:10.5152/tpa.2015.2609

133. Heath TS, Burroughs Z, Thompson AJ, Tecklenburg FW. Acute intoxication caused by a synthetic cannabinoid in two adolescents. J Pediatr Pharmacol Ther (2012) 17(2):177-81. doi:10.5863/1551-6776-17.2.177

134. McKeever RG, Vearrier D, Jacobs D, LaSala G, Okaneku J, Greenberg MI. K2-not the spice of life; synthetic cannabinoids and ST elevation myocardial infarction: a case report. J Med Toxicol (2015) 11(1):129-31. doi:10.1007/ s13181-014-0424-1
135. Ibrahim S, Al-Saffar F, Wannenburg T. A unique case of cardiac arrest following K2 abuse. Case Rep Cardiol (2014) 2014:120607. doi:10.1155/2014/ 120607

136. Davis C, Boddington D. Teenage cardiac arrest following abuse of synthetic cannabis. Heart Lung Circ (2015) 24(10):e162-3. doi:10.1016/j. hlc.2015.04.176

137. Gudsoorkar VS, Perez JA Jr. A new differential diagnosis: synthetic cannabinoids-associated acute renal failure. Methodist Debakey Cardiovasc J (2015) 11(3):189-91. doi:10.14797/mdcj-11-3-189

138. Jinwala FN, Gupta M. Synthetic cannabis and respiratory depression. J Child Adolesc Psychopharmacol (2012) 22(6):459-62. doi:10.1089/cap.2011.0122

139. Alhadi S, Tiwari A, Vohra R, Gerona R, Acharya J, Bilello K. High times, low sats: diffuse pulmonary infiltrates associated with chronic synthetic cannabinoid use. J Med Toxicol (2013) 9(2):199-206. doi:10.1007/s13181-013-0288-9

140. Berkowitz EA, Henry TS, Veeraraghavan S, Staton GW Jr, Gal AA. Pulmonary effects of synthetic marijuana: chest radiography and CT findings. AJR Am J Roentgenol (2015) 204(4):750-7. doi:10.2214/AJR.14.13138

141. Hopkins CY, Gilchrist BL. A case of cannabinoid hyperemesis syndrome caused by synthetic cannabinoids. JEmerg Med (2013) 45(4):544-6. doi:10.1016/j.jemermed.2012.11.034

142. Ukaigwe A, Karmacharya P, Donato A. A gut gone to pot: a case of cannabinoid hyperemesis syndrome due to K2, a synthetic cannabinoid. Case Rep Emerg Med (2014) 2014:167098. doi:10.1155/2014/167098

143. Nacca N, Vatti D, Sullivan R, Sud P, Su M, Marraffa J. The synthetic cannabinoid withdrawal syndrome. J Addict Med (2013) 7(4):296-8. doi:10.1097/ ADM.0b013e31828e1881

144. Macfarlane V, Christie G. Synthetic cannabinoid withdrawal: a new demand on detoxification services. Drug Alcohol Rev (2015) 34(2):147-53. doi:10.1111/dar.12225

145. Sheridan J, Butler R. They're legal so they're safe, right? What did the legal status of BZP party pills mean to young people in New Zealand. Int J Drug Policy (2010) 21:77-81. doi:10.1016/j.drugpo.2009.02.002

146. Hughes B, Griffith P. Regulatory approaches to new psychoactive substances (NPS) in the European Union. Addiction (2014) 108:1591-3. doi:10.1111/ add. 12610

147. Patton AL, Seely KA, Chimalakonda KC, Tran JP, Trass M, Miranda A, et al. Targeted metabolomic approach for assessing human synthetic cannabinoid exposure and pharmacology. Anal Chem (2013) 85(19):9390-9. doi:10.1021/ ac4024704

148. Cannaert A, Storme J, Franz F, Auwärter V, Stove CP. Detection and activity profiling of synthetic cannabinoids and their metabolites with a newly developed bioassay. Anal Chem (2016) 88(23):11476-85. doi:10.1021/acs. analchem. $6 \mathrm{~b} 02600$

149. Drug Enforcement Administration, Department of Justice. Schedules of controlled substances: temporary placement of three synthetic cathinones in schedule I. Final order. Fed Regist (2011) 76:65371-5.

150. European Monitoring Centre for Drugs and Drug Addiction (EMCDDA). Legal Approaches to Controlling New Psychoactive Substances. Luxembourg: Publications Office of the European Union (2015). ISBN: 978-929168-776-3.

151. Rosca P, Bauer A, Khawaled R, Kahana E, Goldman K. The recent legal approach to new psychoactive substances regulation in Israel: does it work? J Civil Legal Sci (2015) 140:1-6. doi:10.4172/2169-0170.1000140

152. Wilkins C. A critical first assessment of the new pre-market approval regime for the new psycho-active substances (NPS) in New Zealand. Addiction (2014) 109:1580-6. doi:10.1111/add.12484

Conflict of Interest Statement: The authors declare that the research was conducted in the absence of any commercial or financial relationships that could be construed as a potential conflict of interest.

Copyright ( 12017 Weinstein, Rosca, Fattore and London. This is an open-access article distributed under the terms of the Creative Commons Attribution License (CC BY). The use, distribution or reproduction in other forums is permitted, provided the original author(s) or licensor are credited and that the original publication in this journal is cited, in accordance with accepted academic practice. No use, distribution or reproduction is permitted which does not comply with these terms. 